\title{
Ballooning: Aeronautical Techniques from Montgolfier to Google
}

Since 2013, the technology company Google has sent hundreds of balloons into the stratosphere. As hovering radio towers, these are intended to provide an internet connection to the approximately 60 percent of the world's population who lack access to the World Wide Web. The balloons' nautical control system is based on algorithms that the tech giant extrapolates from weather data. Neural networks enable these aircraft, which usually cannot be steered horizontally, to move as planned by reading the conditions of the surrounding airspace. To navigate horizontally, the smart balloons move vertically toward targeted air streams. Taking this aeronautical technique as a starting point, this essay will focus on the historical interplay between aircraft knowledge and airspace knowledge. In order to take a critical look at Google's privatization of infrastructures and its economization of the stratosphere, I will concentrate below on two points of contact between balloon flight and meteorology that were forged around the year 1900: unmanned balloon flights and international simultaneous balloon launches. The hypothesis of this essay is that these two activities marked an epistemic turning point at which the ballistic stubbornness of balloons - their inability to be steered horizontally - was put to productive use. Balloons became established media of meteorology. At the same time, these lighter-than-air vessels were an essential impetus behind a transformation in meteorology from a qualitative and observational science into a quantitative and calculating one.

Even though balloons are still used today as meteorological instruments, there have been few historical studies of the interactions between aerostatic and atmospheric knowledge. ${ }^{1}$ At most, historians of technology have regarded these

1 Exceptions include Sabine Höhler, Luftfahrtforschung und Luftfahrtmythos: Wissenschaftliche Ballonfahrt in Deutschland 1880-1910 (Frankfurt am Main: Campus, 2001); Robert Marc Friedmann, Appropriating the Weather: Vilhelm Bjerknes and the Construction of a Modern Meteorology (Ithaca: Cornell University Press, 1993); and Richard Holmes, Falling Upwards: How We Took to the Air (London: William Collins, 2013). In contrast to the historical-epistemological approach to balloons taken in my essay, the cultural geographer Derek P. McCormack has examined them from an ontological perspective. See his book Atmospheric Things: On the Allure of Elemental Envelopment (Durham: Duke University Press, 2018). Furthermore, in his essay "Elemental Infrastructures for Atmospheric Media” (2017), he has explicitly taken Project Loon as a point of reference

Translated by Valentine A. Pakis

Ә Open Access. (C) 2020 Hannah Zindel, published by De Gruyter. (C) BY This work is licensed under a Creative Commons Attribution 4.0 International License.

https://doi.org/10.1515/9783110647044-007 
aircraft, which are filled with hot air or gas, as a failed intermediary stage within a history of technical progress. From the perspective of cultural techniques, however, the balloon is more than just a preliminary stage in the linearly conceived history of technological development - a stage that simply came before steerable blimps and airplanes happened to conquer the skies. It is more than just an actualization - in terms of the history of ideas - of the ancient dream of flying, and it is more than just a spectacular viewing platform or a decorative motif on wallpaper, dishes, and postcards. A research approach based on cultural techniques will enable me to examine the inconspicuous practices associated with balloon flight - techniques that converged at the intersection of widely various fields of knowledge such as observing and charting the surface of the earth, observing and collecting data about the atmosphere, and improving aircrafts and air travel itself. ${ }^{2}$ Initially, these heterogeneous areas of application did not form a consistent epistemic field. From a cultural-technical perspective, however, it becomes clear that balloons have a different relation to the space that they pass through than trains or airplanes, which shoot across the landscape like projectiles. ${ }^{3}$ Aerostats are not only media of that which moves them; they are also media of a type of writing that cannot be removed from the medium that bears the recording and inscribes itself into what has been recorded. The indexical relationship of the aircraft to its surrounding airspace is not only metonymic but reciprocal. Early balloon flight can thus be regarded as a site where concepts of environments and concepts of the relationship between bodies and their environments were repeatedly renegotiated. ${ }^{4}$ These concepts seem to be central to today's efforts to measure, calculate, and simulate the atmosphere, and thus they are also central to our understanding of its privatization and economization, as the example of Google balloons will show.

\footnotetext{
in order to reflect on "atmospheric media" following Mark B.N. Hansen. In this approach, McCormack links Alexander Galloway's and Eugene Thacker's program of focusing on the "ambient," "environmental," "elemental aspects of networks" with approaches from infrastructure studies, in particular Lisa Parks and Nicole Starosielski's socio-technical understanding of "media infrastructures." This essay supplements this approach, which is more interested in ontological questions, with a perspective from cultural techniques and media history.

2 See Hannah Zindel, Ballons: Medien und Techniken früher Luftfahrten (Paderborn: Fink, 2020, forthcoming).

3 See Paul Virilio, "Fahrzeug," in Fahren, fahren, fahren ..., trans. Ulrich Raulff (Berlin: Merve, 1978), 19-50, here 19.

4 See Florian Huber and Christina Wessely, "Milieu: Zirkulationen und Transformationen eines Begriffs," in Milieu: Umgebungen des Lebendigen in der Moderne, ed. F.H. and C.W. (Paderborn: Fink, 2017), 7-17, here 13.
} 


\section{Unmanned Balloons}

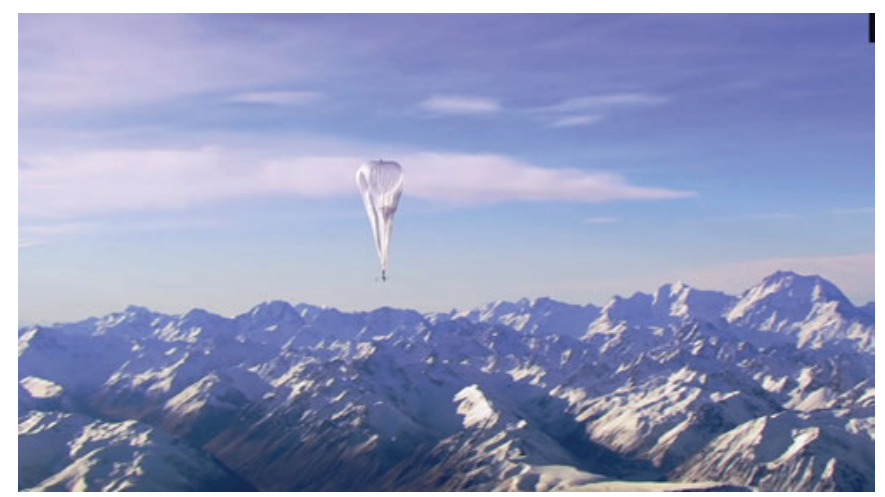

Fig. 1: One of Project Loon's internet balloons.

\section{Internet Balloons}

Google balloons are sent into regions where it is economically challenging to construct communication infrastructure or into regions where such infrastructure has been temporarily damaged by natural catastrophes. The radio towers in the air relocate these infrastructures into the sky. The first tests were conducted in New Zealand in 2013. In 2016, Indonesia became the first nation to access the internet via balloon on a permanent basis. And in October of 2017, Project Loon was granted a license to temporarily replace the communication infrastructure of Puerto Rico, which had been destroyed by Hurricane Maria, with internet balloons. At present, autolaunchers - large mobile scaffolds that automatically fill and launch balloons (Fig. 2) - are supposedly able to release a balloon into the stratosphere every 30 minutes. Every half hour, a new balloon can thus be added to the balloon network. In order to endure the extreme climatic conditions of the stratosphere, the Google balloons and their equipment have to be able to withstand temperatures of up to -90 degrees Celsius, wind speeds of up to 100 kilometers per hour, and intensive UV radiation. ${ }^{5}$ Google balloons reach an altitude of 18 to 21 kilometers and are thus approximately twice as high in the air as passenger planes.

5 See https://loon.com/ (visited on March 30, 2019). Unless otherwise noted, this website is also the source of further information discussed in this section. 


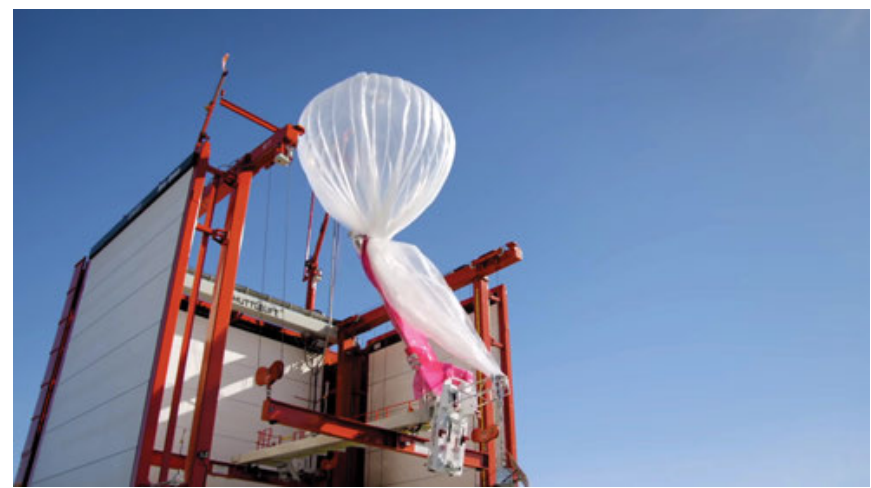

Fig. 2: Autolaunchers can purportedly add a new balloon to the hovering network every 30 minutes.

All of their equipment is highly energy efficient and powered by renewable energy. Solar panels serve as the energy source during the day, and they charge a battery to power the operations during the night. Each of the balloons transports a small box. The latter connects the balloons to one another via laser signals, links them to telecommunication networks via radio waves, and transmits high-speed internet from the stratosphere to smartphones and other LTE-compatible devices on the ground (Fig. 3). ${ }^{6}$ If a balloon needs to be taken out of service, its helium is released through a valve, and the balloon falls back to earth with a parachute.

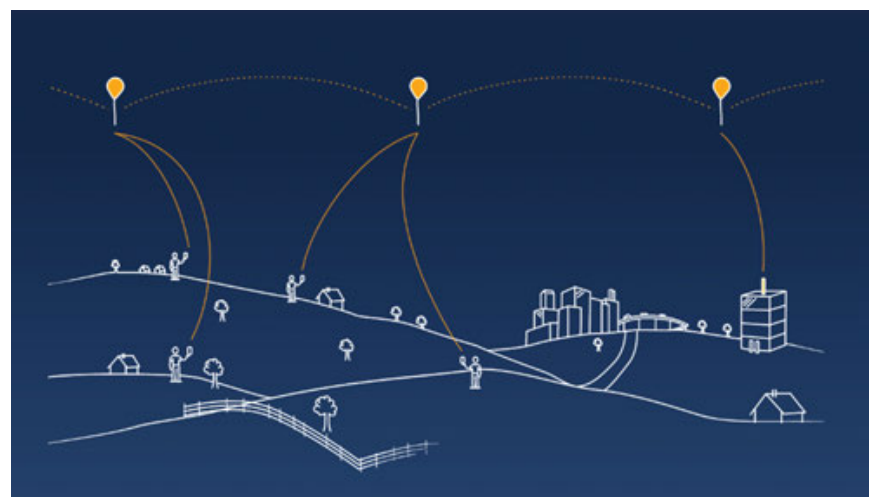

Fig. 3: Internet balloons are linked together through mobile radio towers and LTE-compatible devices.

6 See Tom Simonite, "Project Loon: Billions of People Could Get Online for the First Time Thanks to Helium Balloons That Google Will Soon Send over Many Places Cell Towers Don’t Reach,” Technology Review 118, 2 (2015): 40-45. 
So-called recovery teams then collect all the equipment that has floated down from the sky for the sake of reusing or recycling it.

The name Project Loon is a play on the words balloon and loony. At first, the project was conducted by Google X - the company's research division, which was also working on such things as contact lenses that can measure blood pressure, self-driving cars, and sunglasses equipped with microcomputers. ${ }^{7}$ Google has said about the project that it will serve to make the world a better place by providing internet access to approximately 4.3 billion additional people. What Google touts as a grand humanitarian project is also, of course, a means for the company to access new customers, data, and markets. In order to make a critical assessment of Google's economization of the stratosphere and its privatization of infrastructures, it will be beneficial to take a historicizing and technically informed look at ballooning's techniques for measuring, calculating, and simulating the atmosphere.

\section{From "ballons perdus" to "ballons-sondes"}

In March of 1892, a journalist (and balloonist) conducted a series of experiments together with a scientist on the balcony of an apartment on Paris's Rue de Sébastopol. The two of them attempted to launch small unmanned balloons with selfrecording instruments, including thermographs, hydrographs, and barographs. Gustave Hermite and Georges Besançon built their balloons for sake of studying the upper regions of the sky. ${ }^{8}$ Manned balloons could only be used to investigate the atmosphere up to a certain altitude. At around eight or nine kilometers, the air would become too thin for the human actors in the basket, and even with an oxygen apparatus it was only possible to go a little bit higher. Thirty years earlier, for instance, the altitude at which James Glaisher had lost consciousness $(8,800$ meters) marked a spatial boundary that, in the accompanying research and travel report, had also become visible as an epistemic and aesthetic boundary: higher regions were inaccessible to the established recording methods of the time and were thus beyond the limits of existing knowledge. ${ }^{9}$

7 Since the beginning of 2018, Google X has been a subsidiary company called X, just as Google itself is now a subsidiary of the parent company Alphabet. However, because internet balloons are commonly referred to as "Google balloons," I will continue to use the term here.

8 On Hermite and Besançon's unmanned balloons, see Wilfrid de Fonvielle, Les ballons-sondes de MM. Hermite et Besançon et les ascensions internationales (Paris: Gauthier-Villars et fils, 1898). 9 See Hannah Zindel, "À ballon perdu: Forscherohnmacht an einem bewölkten Septembernachmittag 1862," in Versteckt - Verirrt - Verschollen: Reisen und Nicht-Wissen, ed. Irina Gradinari et al. 
In the unmanned balloon flight attempted by the two Frenchmen in 1892, the problem of unconscious instrument readers on board was avoided by means of self-recording instruments. What was true of the epistemic subject, however, did not at all apply to the subject who more or less steered the balloon. It was nearly impossible to replace balloon captains as well. How were unmanned balloons supposed to land? How could they ever be found again? With no one on board, there would be no indications regarding the location of the balloon. Hermite and Besançon therefore devised a specific apparatus for landing and rediscovering their unmanned balloons (Fig. 4). They designed their aircraft in such a way that recording, landing, and rediscovery were partially automated. The instrument box with the self-recording devices, which hung from the balloon, was designed to sail back to earth with a parachute.

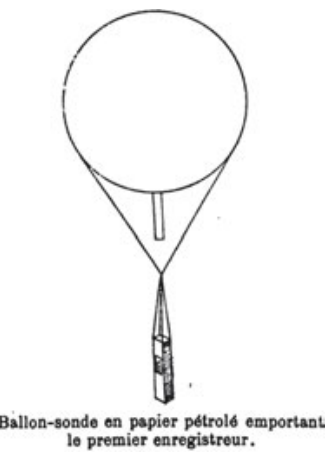

Fig. 4: An unmanned paper balloon with self-recording instruments, 1892.

The balloon itself was made of rice paper, so that it would burst at a particular altitude. ${ }^{10}$ The problem of ensuring that the balloons would fall from the sky was thus solved by using this fine paper. Yet how would it be possible to find them once they had landed? The two men experimenting on the balcony attached a bundle of postcards to each balloon; from this bundle, a single postcard would be released at regular intervals by means of a slow-burning wick. Those who found the cards were requested to write down the location of the discovery and return them to the address provided. The final postcard remained fixed to the balloon through its landing.

(Wiesbaden: Reichert, 2016), 347-366; and Zindel, “Clouds and Balloons: James Glaisher’s Travels in the Air," in Silver Linings: Clouds in Arts and Sciences, ed. Dolly Jørgensen (Trondheim: Museumsforlaget, 2020), 27-37.

10 By using this paper instead of rubber-coated silk (which was more common at the time), the two tinkerers were in fact reverting to the material that had been used by the brothers and paper manufacturers Jacques-Étienne and Joseph Montgolfier during the early years of balloon flight in the late eighteenth century. 
This semi-automated version of tracking balloons had various precursors. ${ }^{11}$ Balloon travelers were followed by so-called pursuers on horseback, for instance. Postal techniques, too, had also been relied upon earlier. Moreover, carrier pigeons were brought along aboard balloons and returned one-by-one to the place of departure with short notes about the present time and location of the passengers. The last pigeon would usually be sent back from the location of a balloon's landing. In the event that passengers happened to know their location, they would send a request via this pigeon to be picked up there (along with the all the equipment, which was not exactly light) by a cart or a carriage (Fig. 5). The spatial logic of balloons and that of carrier pigeons thus complemented one another quite well when it came to issues of locating and addressing. Whereas balloons have a starting point $A$ with $n$ possible destinations, pigeons have $n$ possible starting points and one destination $B$, their home pigeonhole.

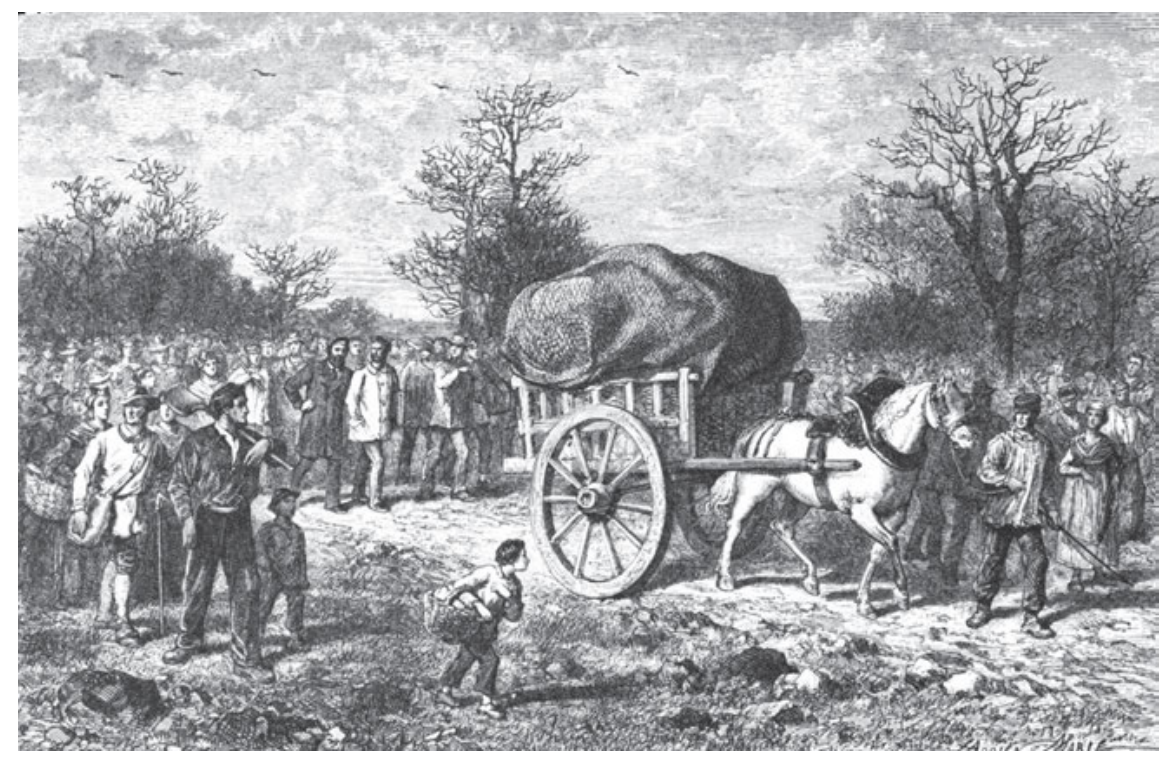

Fig. 5: Loading heavy aircraft equipment.

Another postal technique was to drop prepared postcards. These, as in the case of Hermite and Besançon's balloons, would request that the discoverer of the card send it back to the given address with a note about the time and location of the

11 See Hannah Zindel, "Belagerung von Paris: 69 Freiballons, 381 Tauben und fast 11 Tonnen Post," in Medien - Krieg - Raum, ed. Lars Nowak (Munich: Fink, 2018), 141-160. 
discovery. Later, balloonists would throw prepared telegrams overboard (Fig. 6). In addition to the delayed tracking of balloons through the mail and telegraphy, the simultaneous observation of traveling aerostats also became an established tracking method. During the early years of balloon travel, the Parisian Academy of Sciences had been unsuccessful in its attempts to record flight paths by stationing observers at certain places in advance. But it became common during the second half of the nineteenth century for local presses to publicize upcoming balloon flights, so that sightings could be reported in the newspapers.

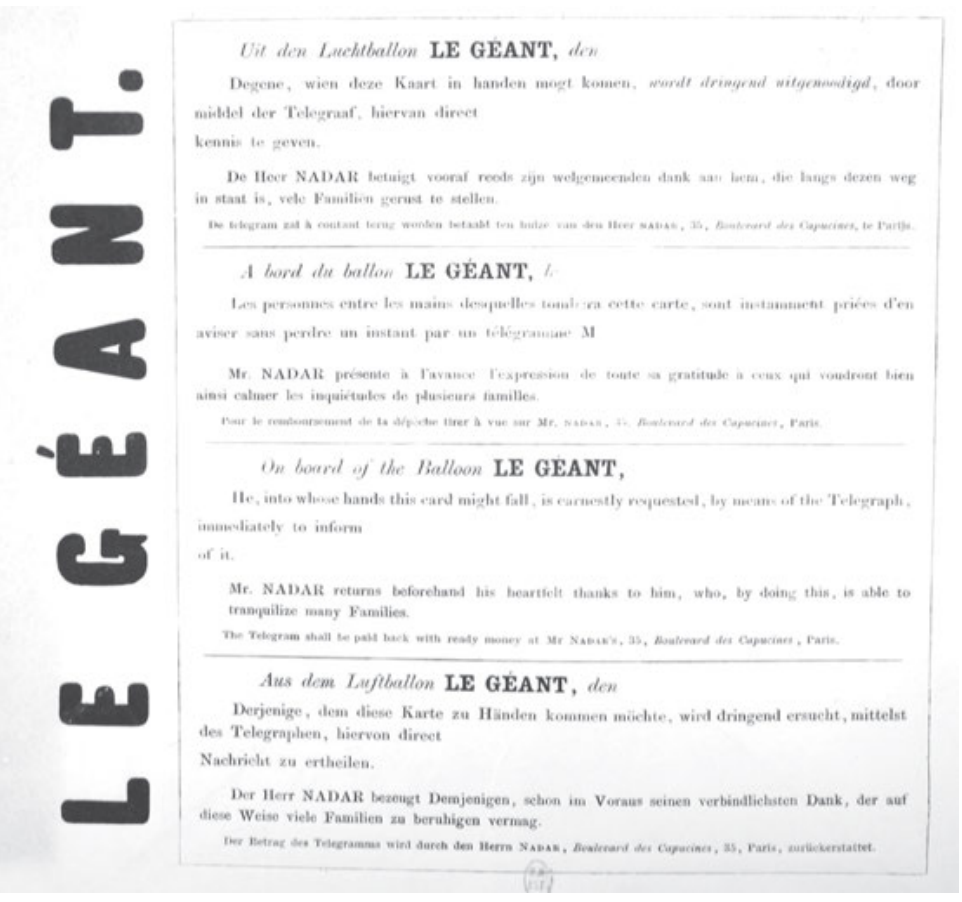

Fig. 6: A route-tracking telegram by the balloonist and photographer Nadar.

These tricks discursivized and standardized a knowledge of airspace that factored in the uncontrollable nature of the balloon. Although it was unpredictable where a balloon would end up (on account of its inability to be steered horizontally), it was absolutely predictable that it would crash back down to earth at some point. Hermite and Besançon therefore made it their objective to turn the dropping of postcards into the standard form of communication for this type of air travel.

One term used during the early years of balloon flight reflects the negative connotations that had, to this point, been associated with the ballistic peculiarities of unmanned balloons: a balloon trip without passengers was also referred 
to as a ballon perdu, a "lost balloon." ${ }^{2}$ In 1899, the meteorologist and balloon traveler Wilfrid de Fonvielle pointed out that, in order to market their unmanned balloons for an exploratory trip to the North Pole, ${ }^{13}$ Hermite and Besançon had strategically replaced the term ballon perdu with the designation ballons-sondes. The negatively connotated perdre ("to lose," "to leak") was thus replaced with sonder ("to survey," "probe," "sound out"). This rebranding metaphorically condensed the shift that had been taking place in ballooning around the year 1900: a shift away from a project of disruptions and interruptions toward a project of flowing functionality.

Moreover, it also concerned the aesthetic question of charting and reproducing a trace - in the case of balloons, the question of documenting a moving object in three-dimensional space. ${ }^{14}$ The methods for tracing and tracking balloons were all highly imprecise; the lag time between the event itself and its recording would lead to imagined arabesque or interrupted lines instead of calculated and continuous trajectories. The exploration of the upper regions of the sky was not only a matter of improving measurements of air temperature, humidity, and air pressure. In the nineteenth century, high-altitude flights were also about optimizing the techniques of addressing, tracking, and tracing.

\section{From "ballons-sondes" to Radiosondes}

At the turn of the twentieth century, unmanned balloons were no longer being used exclusively as so-called pilot balloons, which would be released in advance

12 See Dieter Zastrow, Entstehung und Ausbildung des französischen Vokabulars der Luftfahrt mit Fahrzeugen "leichter als Luft" (Ballon, Luftschiff) von den Anfängen bis 1910 (Tübingen: Niemeyer, 1963), 39.

13 In the 1880s, the two inventors attempted to figure out how to execute the idea - first suggested in a publication by Delavile Decreux in 1863 - of making an excursion to the North Pole in a balloon. Although unmanned balloons were never used for polar explorations, Hermite and Besançon did prepare and train the scientist Salomon Auguste Andrée, who did in fact set out for the North Pole in 1897 in a balloon with two other passengers. See Wolfgang Struck, "Ingenjör Andrées luftfärd oder Die melancholischen Entdeckungen des Films," in Literarische Entdeckungsreisen: Vorfahren - Nachfahrten - Revisionen, ed. W.S. and Hansjörg Bay (Cologne: Böhlau, 2012), 29-52; and Kristina Kuhn and W.S., Aus der Welt gefallen: Die Geographie der Verschollenen (Paderborn: Fink, 2019).

14 It is rather symptomatic of balloon flight that the mathematician Leonard Euler happened to die in 1783 (shortly after the launch of the first Montgolfière) while trying to calculate the trajectory of a balloon. See Charles Coulston Gillispie, Sciences and Polity in France: The Revolutionary and Napoleonic Years (Princeton: Princeton University Press, 2004), 535. 
of balloon launches in order to observe the approximate direction in which the manned balloon might travel. Despite the difficulty of determining their flight trajectory and their frequent disappearance, at the close of the nineteenth century they began to play an important role in studying the atmosphere, especially the upper regions of the sky. In 1896, Hermite and Besançon introduced their method at one of the first international meteorology conferences. Soon thereafter, the French meteorologist Léon-Philippe Teisserenc de Bort began to launch unmanned weather balloons systematically, and in 1902 he differentiated the atmosphere into the troposphere and the stratosphere. ${ }^{15}$

As of the beginning of the twentieth century, unmanned balloons became established meteorological instruments and were observed by means of theodolites, which functioned well in daylight but were difficult to use at night and during periods of bad weather even though lanterns would be held up beside them. ${ }^{16}$ In meteorology, too, an improvement in measurement technology was tied to more sophisticated techniques of addressing, tracking, and tracing. Lag time between measuring and recording had to be minimized in order to justify meteorology's claims of being a prognostic science. ${ }^{17}$ This required new developments in communications technology.

As before, the main application of unmanned balloons was to explore the climatically extreme stratosphere, which lay beyond the limits of manned balloon travel. In the 1860s, the French photographer and aeronaut Félix Nadar was still extolling balloons as instruments for observing the movement of soldiers, in which case the balloonist in the basket was supposed to deliver finished drawings to the field commander by means of a rope. ${ }^{18}$ Now, however, the field of meteorology was attempting to use wires instead of rope and electrical signals instead of drawings. In 1843, for instance, the English physicist Charles Wheatstone had introduced the first "telemeteorograph." This was a device that made it possible to transmit data from thermometers, barometers, and hygrometers over multiple kilometers through a wire. In the same year, he presented a telemetering

15 See Jean Mascart, "L'étude de la haute atmosphere et les travaux de Léon Teisserenc de Bort," La Nature 2080 (April 5, 1913): 296-300.

16 See John L. Dubois et al., The Invention and Development of the Radiosonde, with a Catalog of Upper-Atmospheric Telemetering Probes in the National Museum of American History, Smithsonian Institution (Washington, DC: Smithsonian Institution Press, 2002), 26.

17 See Matthias Heymann et al. (eds.), Cultures of Prediction in Atmospheric and Climate Science: Epistemic and Cultural Shifts in Computer-Based Modeling and Simulation (New York: Routledge, 2017).

18 See Nadar, When I Was a Photographer, trans. Eduardo Cadava and Liana Theodoratou (Cambridge, MA: MIT Press, 2015 [1900]), 59. 
thermometer. The latter, which was meant to be used with a tethered balloon, transmitted signals through two copper wires to a receiver on the ground. ${ }^{19}$

However, the conversion of analog weather data (noted on paper by selfrecording instruments) into discrete data, which would be suitable for the transmissions of electromagnetic telegraphy, could only be accomplished if the discoverer of the balloon probe knew how to interpret the recordings. A central precondition for this further processing was thus the development of a digital meteorograph, so that it would no longer be necessary to convert analog measurements into digital signals. The latter was developed in 1896 by Luigi Cerebotini and Albert Silbermann, who patented their invention in the United States in $1900 .{ }^{20}$ In the 1920s, this system would be used by Robert Bureau in his design of the first radiosonde. For it was not until 1929 that wireless communications technology had progressed to the point that it could also be used with balloons: from the ballon-sonde thus emerged the so-called radiosonde (Fig. 7). During the

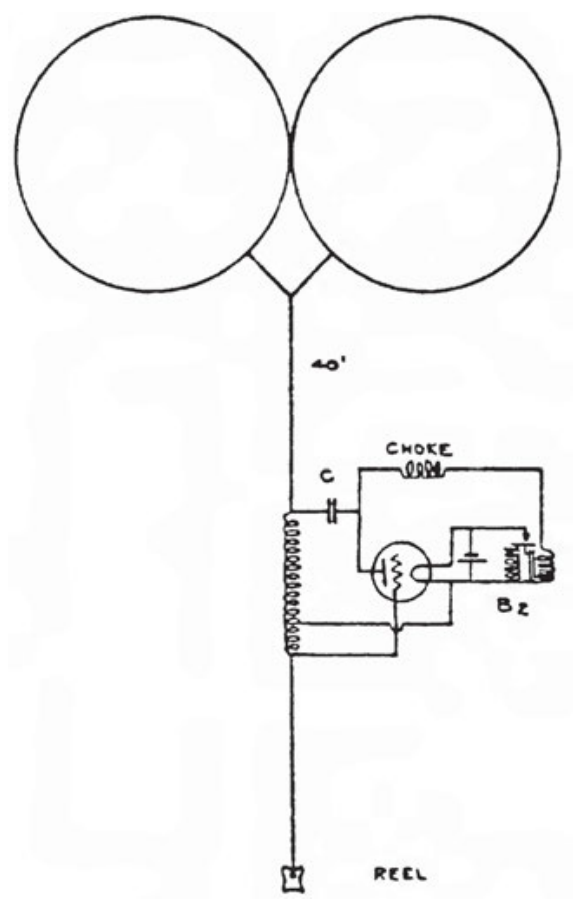

Fig. 7: William Blair's first radio-tracking transmitter, circa 1923-1924.

19 See Dubois et al., The Invention and Development of the Radiosonde, 15. This concept would not be tried again until 1917.

20 See Dubois et al., The Invention and Development of the Radiosonde, 18. 
development of the radiosonde, the meteorologists of the 1920s were engaged first and foremost with the problem of making existing transmitter technologies function in the environment of balloons. This was a matter of adapting radio and transistor technology for free-floating balloons. ${ }^{21}$

During the 1920s, meteorology, balloon flights, and communications technology thus worked strategically together to improve military surveillance and economically relevant weather forecasting. A radiosonde was not only an unmanned balloon on which instruments could register data; it could also wirelessly communicate these data from a transmitter to the ground. Wireless tracking with radio signals made it possible to track balloon trajectories and thus, in addition, to measure the speed and direction of the wind and to determine wind vectors. After more than 140 years of experimenting on the techniques of tracking, tracing, and addressing in balloon flight, the fact that balloons could not be controlled was turned into a positive episteme.

\section{Simultaneous Launches}

\section{Balloon Navigation from Kleist to Algorithms}

One special feature of Google balloons is the fact that they can be navigated to move both vertically and horizontally. To achieve this, Google had to devise a technique of its own:

In the stratosphere winds are stratified, and each layer of wind varies in speed and direction. To get balloons to where they need to go, Project Loon uses predictive models of the winds and decision-making algorithms to move each balloon up or down into a layer of wind blowing in the right direction. By moving with the wind, the balloons can be arranged to provide coverage where it's needed. ${ }^{22}$

21 In 1921, Hugo Hergesell began to experiment with balloon-borne radio transmitters at the Lindenberg Observatory in Berlin. In France, Pierre Idrac and Robert Bureau, who were both employed by l'Office National Météorologique, launched free balloons with radio transmitters to an altitude of 14 kilometers in the stratosphere. Around the same time, William Blair, who was working at the Signal Corps Laboratory in Monmouth, New Jersey, managed to design and construct an oscillator for stratosphere balloons. As of 1928, these transmitters were flown extensively with clusters of four to six theodolite-tracked balloons (see Dubois et al., The Invention and Development of the Radiosonde, 29).

22 Quoted from https://gnsec.wordpress.com/2017/07/12/technology-project-loon/ (visited on April 9, 2019). Vertical navigation functions by means of a built-in air pump that pumps air into or 
The balloons have taken millions of kilometers of test flights and have collected weather data about these stratifications at various altitudes. On the basis of these data, software algorithms can now determine at which altitude the chances would be highest to locate an air stream in which a balloon would be able to remain for an extended time over a given area. The act of heading toward particular wind currents is controlled by software in one of Google's data centers, which incorporates wind forecasts from the U.S. National Oceanic and Atmospheric Administration in its simulations of stratospheric air streams. For these simulations, Google now relies on neural networks. Google balloons navigate by moving up or down into the appropriate current. ${ }^{23}$ In this way, a balloon can remain for a longer period of time over a region that lacks widespread internet access. Knowledge about the stratosphere is measured in situ by sensors and is processed, stored, and retrieved at data centers that possess the necessary amount of computing power.

With the step from balloons to Loons, navigation has shifted from an unpredictable external force to a type of control that is realized by means of the wind. Control is not conceptualized and actualized on the basis of the moving object but rather on the basis of the space that surrounds it. Both approaches - the direct and indirect control of balloons - were also implemented in the nineteenth century.

Even in the early years of balloon travel, the desire for a controllable aircraft and controllable airspace necessitated the development of a new form of aerostatic and atmospheric knowledge. Numerous bold designs only ever existing on paper imagined the utopia of a technically exploitable airspace in which balloons could circulate as flying carriages or ships, and in which the terrestrial logic of space could be imposed on the sky. ${ }^{24}$ At the same time, there also appeared another approach to controlling this aircraft by harnessing the logic of the airspace itself. This approach stems from Heinrich von Kleist, who wrote the following in 1810:

The oilcloth manufacturer Mr. Claudius intends ... to travel into the air ... with a balloon and to steer it in a particular direction by means of a machine and thus independent of the wind. This undertaking seems strange, because the art of moving a balloon without any

removes air from a small balloon located within the large balloon and thus regulates the density of helium within the balloon as a whole. This technology enables the balloon to ascend or descend. 23 See Simonite, "Project Loon," 44.

24 See Elske Neidhardt-Jensen and Ernst Berninger, Katalog der ballonhistorischen Sammlung Oberst von Brug: Fluglust - Fluges Beginnen - Fluges Fortgang (Munich: Deutsches Museum, 1985), 59, 151, 161 (among many other examples in the book). 
machinery - and in a quite easy and natural manner - has already been discovered. For, up in the sky, all possible currents (winds) overlap one another, and thus the aeronaut needs only to use vertical movements to locate the airstream that will lead him to his destination. ${ }^{25}$

According to Kleist, balloons can be controlled by intentionally harnessing the power of particular wind currents. Kleist's approach to solving the problem of navigability belonged to the domain of meteorology instead of mathematics; at least at the beginning of the nineteenth century, that is, this practice was more unpredictable and incalculable than not. ${ }^{26}$ Over the course of the nineteenth century, however, meteorology transformed from a science that collected qualitative data into one that gathered quantitative data. In order to describe this transition, it will be beneficial to revisit a central scene in the history of balloon travel where meteorology was interwoven with mathematics and thus observation was integrated with calculation: the simultaneous balloon launches that took place around the year 1900.

\section{Balloon Clusters and Wind Patterns}

In 1896, a balloon was launched from the small Swiss town of Sion in the first attempt to cross the Alps. This Alpine journey occasioned the first European-wide simultaneous ascent - in Paris, St. Petersburg, Berlin, and Strasbourg. This simultaneous launch was organized by the Internationale aeronautische Kommission, which was also known as the Internationale Kommission für wissenschaftliche Luftfahrt. ${ }^{27}$ As of this committee's second conference, which was held in 1900, simultaneous launches were systematically implemented as an observation program. ${ }^{28}$ For, as one author remarked about the simultaneous launches that took place in 1902, a year in which 150 of them were undertaken in Europe and

25 Heinrich von Kleist, "Schreiben aus Berlin,” in Sämtliche Werke: Brandenburger (Berliner) Ausgabe, ed. Roland Reuß and Peter Staengle (Frankfurt am Main: Stromfeld, 1888-2002), vol. 1, 65-66, 1. 25-30; translation from the German by Valentine A. Pakis.

26 See Roland Borgards, "Experimentelle Aeronautik: Chemie, Meteorologie und Kleists Luftschiffkunst in den Berliner Abendblättern,” Kleist-Jahrbuch (2005): 142-161.

27 See Höhler, Luftfahrtforschung und Luftfahrtmythos, 286-289. The idea for this simultaneous launch arose in September of 1896 in Paris at a meeting held by the directors of meteorological institutes from various countries in an effort to organize observations of the atmosphere across national borders. It was at this same conference that Hermite and Besançon introduced their unmanned balloons.

28 See Höhler, Luftfahrtforschung und Luftfahrtmythos. 
the United States, "our highly inadequate understanding meteorological laws ... [needs] to be augmented by studies of the upper strata of the atmosphere."29

Data from the network of terrestrial weather stations were supplemented by data gathered in the upper regions of the sky. According to the meteorologist Julius Maurer's report about his balloon flight over the Alps, these supplemental data would make it possible to study not only local weather phenomena but also the global structure of weather conditions (Fig. 8). ${ }^{30}$

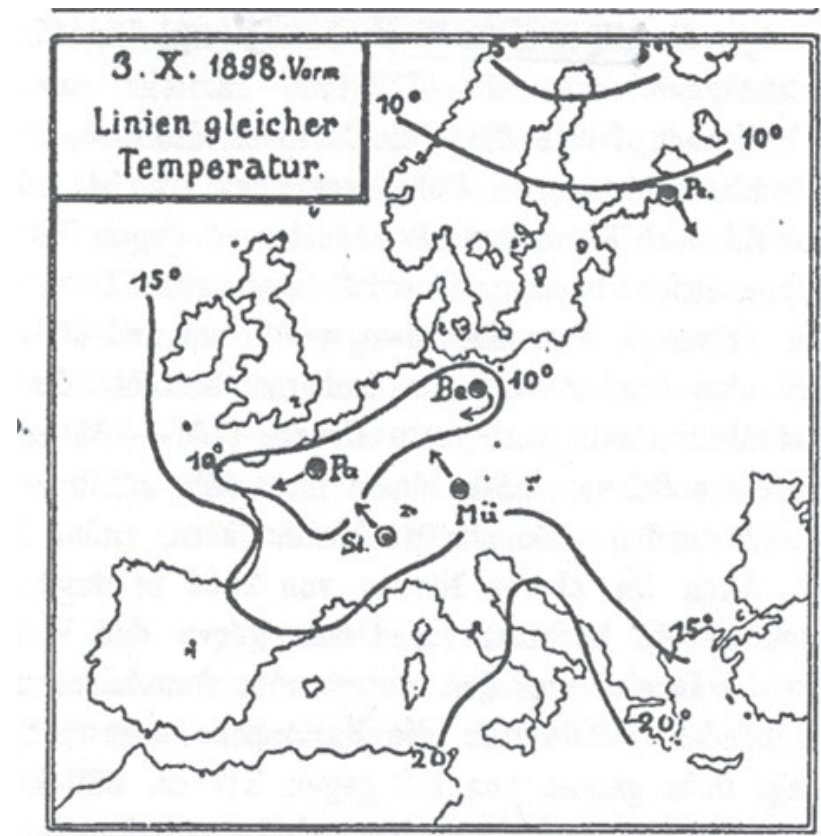

Pfeile - Flugrichtung der Bullons.

Fig. 8: The launch sites and wind directions of a European-wide simultaneous balloon ascent, 1898.

29 Alexander Supan, “Die internationalen Luftfahrten im Jahre 1902," Petermann's geographische Mittheilungen 50 (1904): 128-129, here 128; translation from the German by Valentine A. Pakis. A better understanding of the atmosphere was not only of interest for purposes of weather forecasting. It was rightly believed that weather forecasting would be of interest to agriculture as well as the military (see Friedman, Appropriating the Weather, 109). Commercial air travel would benefit from this knowledge later on.

30 Julius Maurer, "Die meteorologischen Ergebnisse," in Albert Heim et al., Die Fahrt der "Wega" über Alpen und Jura am 3. Oktober 1898 (Basel: Schwabe, 1899), 82-125, here 119. In addition to Maurer, the others on board this flight were the mountain geologist Albert Heim and the balloonist and photographer Eduard Spelterini. 
As historians of science have shown, the field of aerology played a significant role in the development of meteorology into a geographical and statistical science. Around the year 1900, meteorology transformed into a science devoted to "the quantitative recording of all environmental conditions." 31 The international collaboration of scientists on simultaneous balloon launches contributed to the establishment of atmospheric physics and to the formation of scientific guidelines for systematically measuring and charting the open air. ${ }^{32}$ It was thus with the help of aerology that meteorology was able to transform from a science based on empirical observations into one grounded in theories and calculations.

\section{Ballooning and Weather Forecasting}

Collecting quantitative data is well and good, but what should be done with all the data? As of 1902, the data collected during the simultaneous balloon ascents flooded the desk of the chairman of the Internationale aeronautische Kommission in Strasbourg, Hugo Hergesell, in the form of standardized tables. There was so much new information, however, that at first no one was able to evaluate it. ${ }^{33}$

In 1904, the meteorologist Vilhelm Bjerknes therefore encouraged his colleagues to replace, on account of its inaccuracy and long delays, the graphical and synoptic evaluation of such data - as had been practiced with a chart, for instance, by the meteorologist Julius Maurer during his flight over the Alps - with a precise theoretical evaluation based on equations derived from the physical laws of the atmosphere. ${ }^{34}$ This sort of weather forecasting would first be implemented in practice by the Englishman Lewis Fry Richardson, who published his results in his 1922 book Weather Prediction by Numerical Process, which likewise included a chart (Fig. 9).

Richardson proposed the following method: divide the earth's atmosphere into cubic regions and entrust each of the latter to someone proficient in mathematics. These researchers should take measurements of the temperature,

31 Höhler, Luftfahrtforschung und Luftfahrtmythos, 215.

32 See Höhler, Luftfahrtforschung und Luftfahrtmythos, 284-285.

33 In 1903, the gathered data was published in the Veröffentlichungen der internationalen Kommission für wissenschaftliche Luftschiffahrt, so that it could at least be made available to researchers.

34 See Friedman, Appropriating the Weather. In the absence of other ways to evaluate data, synoptic meteorology continued to be practiced into the 1970s. With this method, the movement of weather fronts could be represented in a graphical form. Maurer himself admitted the that, among other problems with this approach, the temperature measurements taken in balloons can be highly inaccurate (see Maurer, "Die meteorologischen Ergebnisse," 93, 104). 


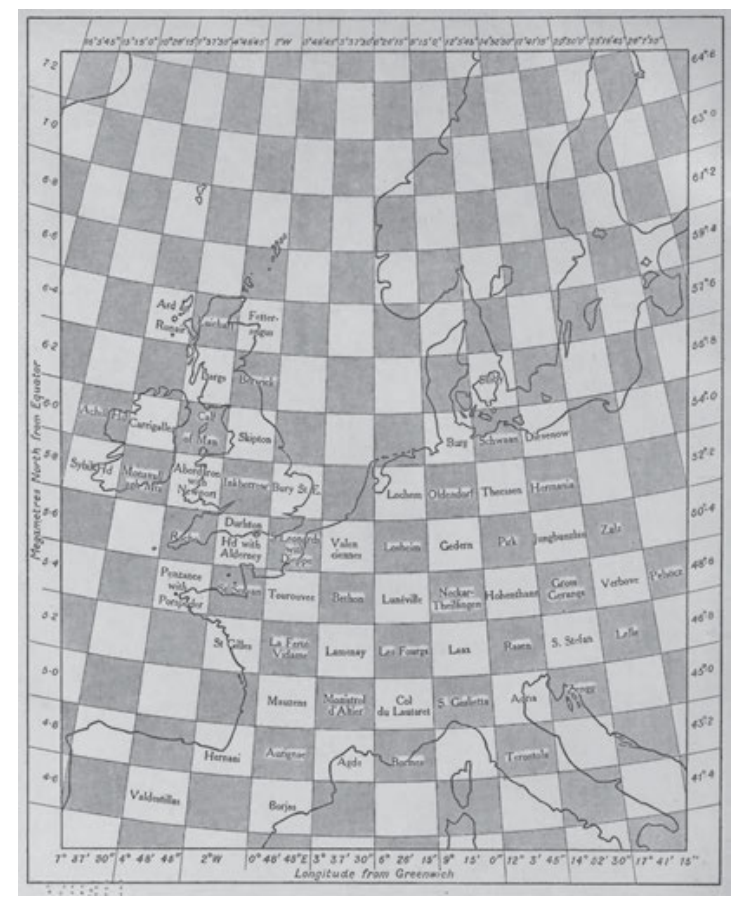

Fig. 9: Lewis Fry Richardson's map of Europe for numerical weather forecasting, 1922.

humidity, and pressure in their respective region and insert such data into formulas. The results should then be shared with those making the same calculations on adjacent regions. In order to test his formulas (which were based on physical laws) and the practicability of his method, Richardson worked through the necessary calculations for an example in 1917. His idea was to produce - long after the fact - a weather forecast for the day of May 20, 1910.

Because of the many simultaneous balloon launches undertaken over the course of the three previous days - known in English as "International Aerological Days" - there was, for May 20, a relative abundance of available data about the upper atmospheric regions, and this data set served as an especially good point of reference. After six weeks of making calculations, Richardson's results turned out to be false, but he had nevertheless demonstrated that numerical forecasting was fundamentally possible:

In Ch. 9 will be found an arithmetical table showing the state of the atmosphere observed over middle Europe at 1910 May 20 d. 7 h. GMT [Greenwich Mean Time]. This region and instant were chosen because the observations form the most complete set known to me at 
the time of writing ... Unfortunately this "forecast" is spoilt by errors in the initial data for winds. These errors appear to arise mainly from the irregular distribution of pilot balloon stations, and from their too small number. ${ }^{35}$

As Richardson remarks, his calculations were off the mark on account of certain errors in the data set pertaining to May 20,1910, but he was confident that he had proven the viability of his approach. In order to speed up his method so that it could produce weather forecasts in real time (instead of being delayed by six weeks), he imagined a sort of forecasting factory (Fig. 10). His utopian vision of

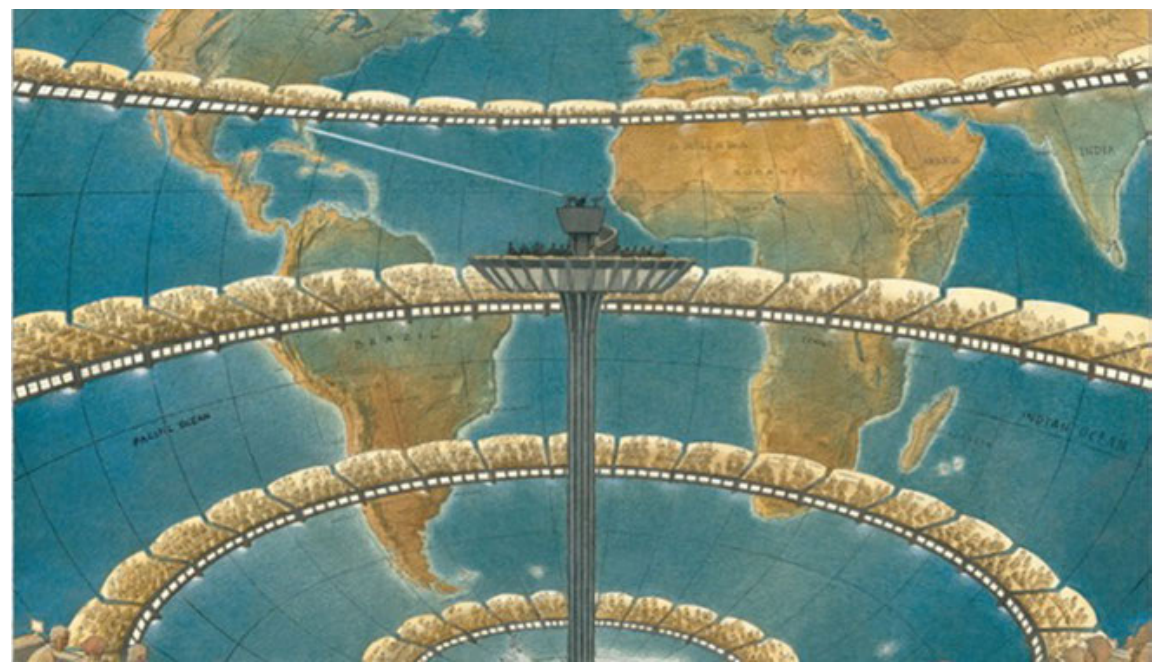

Fig. 10: Richardson's weather-forecasting factory (illustrated by François Schuiten).

a totally measurable and calculable world took the form of a large theater with 64,000 human computers, each responsible for performing calculations about a particular region of the sky and conveying this information to those working adjacently. This was of course impracticable, and forecasts of this sort would not be generated until the advent of the automated computer and its sufficient processing power. Today's forecasting models are all based on numerical methods, which are fed by new measurement data every six hours. ${ }^{36}$ An increasing number of

35 Lewis Fry Richardson, Weather Prediction by Numerical Process (London: Cambridge University Press, 1922), 2.

36 See Gabriele Gramelsberger, Computerexperimente: Zum Wandel der Wissenschaft im Zeitalter des Computers (Bielefeld: transcript, 2010). 
weather stations and ever-expanding computing power has admittedly enhanced the accuracy of more recent weather simulation, but the same problem of mathematical modeling that had created difficulties for Richardson still remains: minor deviations in input data can cause major deviations in output data. ${ }^{37}$

\section{Concluding Remarks}

Around the year 1900, knowledge about aircraft and knowledge about airspace coalesced into an epistemic turning point at which the ballistic stubbornness of balloons - their inability to be navigated horizontally - was used in a productive manner. Technology and practices for measuring, calculating, and simulating aerostatic and atmospheric dynamics were developed and established at several points of contact between balloon travel and meteorology. This essay has made clear, first, that unmanned balloons could be used as an instrument for tracking and recording balloon trajectories and wind vectors. Second, it has shown that simultaneous balloon launches could serve as a starting point for integrating data about local wind vectors and thereby identifying the structures of global weather conditions.

Examining these developments from a cultural-technical perspective makes it possible to describe Google's balloons in critical terms beyond the informational material provided by the tech giant itself and to illuminate the historically shifting references between travel space and traveled space, observing space and observed space, as well as calculating and calculated space. Because the sky could, from the outset, only be reached with machines, balloon flights served as a model for the epistemic specifics of the production of geographical knowledge in the nineteenth century: by means of particular technologies and practices, scientists constructed spaces, and as travelers found themselves subjected to the contingencies of these spaces. ${ }^{38}$

In the case of Google balloons, not only do the balloons become part of communication infrastructure; the stratosphere itself becomes infrastructure. Google balloons measure physical space and navigate by means of mathematical space. Google's stratosphere is not a thermodynamic space of random air currents and turbulence but rather a mathematically modeled and computer-simulated space; it is not unpredictable nature but rather a calculable and predictable environment.

37 See Gramelsberger, Computerexperimente.

38 See Johannes Fabian, Im Tropenfieber: Wissenschaft und Wahn in der Erforschung Zentralafrikas (Munich: C. H. Beck, 2001), 243-280. 
This invites a historicizing media-theoretical and cultural-technical perspective from which it is possible to elucidate this "infrastructure-becoming" in light of its interwoven spatial, technical, and social aspects, ${ }^{39}$ and from which it is also possible to describe collectives not only as metaphors but also as materialized and materializing agents that have become operative on a geopolitical level. ${ }^{40} \mathrm{~A}$ cultural-technical perspective can make it possible to describe this "infrastructure-becoming" not only in light of its epistemic implications but also in light of its geopolitical implications. This raises not only the question of the extent to which balloon collectives are both abstract media of the space surrounding them and media of recording but also the question of how unmanned balloons and simultaneous ascents as such have formed, quite concretely, the ideal of a disruption-free airspace in which information can circulate without the distorting effects of noise.

With Project Loon - i.e., with the transition from balloons to Loons - these aircraft have become smart objects. The term "internet of things" implies that objects denoted as "smart" are "networked and context-dependent" and that they "operate on the basis of sensor data collected on a large scale." ${ }^{41}$ They function independently, "in that they not only collect data but also predict future events or even make decisions on the basis of these data." ${ }^{42}$ The aim of these twentieth-firstcentury media is "to predicatively extrapolate, monitor, control, and ultimately economize (on the deepest level) movements, knowledge, and processes on the basis of sensor data." ${ }^{43}$ In this light, one could maintain that Google's Project Loon economizes the stratosphere with its smart balloons and implements surveillance from it. This type of control via geographical and mathematical space is simultaneously a form of regulating sociotechnical space. Moreover, the borderless network of mobile, hovering radio towers is by no means stateless. Although governments can fill out a contact form on the project's homepage, legal regulations are a matter of negotiation or are undisclosed.

The alternative projects that have popped up to compete with Google's Project Loon are indicative of how lucrative it can be for large service providers

39 See Schabacher, "Medium Infrastruktur," 129.

40 See Lorenz Engell and Bernhard Siegert, “Einleitung,” Zeitschrift für Medienphilosophie und Kulturtechnikforschung 3, 2 (2012): 5-13.

41 Florian Sprenger and Christoph Engemann, "Im Netz der Dinge: Zur Einleitung," in Internet der Dinge: Über smarte Objekte, intelligente Umgebungen und die technische Durchdringung der Welt, ed. Sprenger and Engemann (Bielefeld: transcript, 2015), 7-58, here 8.

42 Sprenger and Engemann, "Im Netz der Dinge," 8.

43 Sprenger and Engemann, "Im Netz der Dinge," 9. Here Sprenger and Engemann refer to Marc B.N. Hansen, Feed-Forward: On the Future of Twenty-First-Century Media (Chicago: University of Chicago Press, 2014), 4. 
to make private mobile infrastructures available. Under the catchphrase "internet for everyone" - or, in Google's case, "Loon for everyone" - a competition has begun among infrastructures and transmission techniques. Companies such as Facebook and Tesla are likewise conducting experiments in the stratosphere with ultra-lightweight aircraft, solar-powered drones, and low-flying satellites. The internet for everyone implies a utopian vision of networking everyone and everything - and thus making everyone and everything calculable and predictable. 
